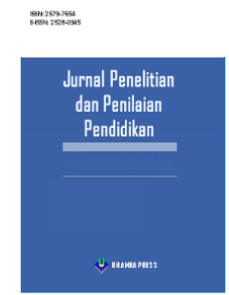

\title{
PENINGKATAN HASIL BELAJAR MELALUI PEMBELAJARAN PBL PADA SISWA SMPN 1 TEMPEH
}

\section{Siti Sarafiah | Hari Setiadi| Sri Yuliawati}

How to cite : Sarafiah, Siti., Setiadi, Hari., \&Yuliawati, Sri., 2021. PENINGKATAN HASIL BELAJAR MELALUI PEMBELAJARAN PBL PADA SISWA SMPN 1 TEMPEH. Jurnal Penelitian dan Penilaian Pendidikan. 3(2). 170 - 178.

To link to this article : https://doi.org/10.22236/jppp.v3i1.6804

(C2021. The Author(s). This open access article is distributed under a Creative Commons Attribution (CC BY-SA) 4.0 license.

Published Online on 30 July 2021

14 https://journal.uhamka.ac.id/index.php/jppp

View Crossmark data $₫$ 


\title{
PENINGKATAN HASIL BELAJAR MELALUI PEMBELAJARAN PBL PADA SISWA SMPN 1 TEMPEH
}

\author{
Nuril Husniah $^{1}$, Harsunarko $^{2}$, Imam Syafei $^{3}$ \\ ${ }^{1}$ STIKES Griya Husada Sumbawa \\ 2,3 Universitas Muhammadiyah Prof DR HAMKA \\ E-mail: $\quad$ nuril.husniah@gmail.com ${ }^{l)}$ \\ harsunako@uhamka.ac.id ${ }^{2)}$ \\ imam.syafei@uhamka.ac.id ${ }^{32}$
}

Received: 9 April 2021

\begin{abstract}
Abstrak
Penelitian bertujuan meningkatkan hasil belajar siswa pada mata pelajaran IPA dengan menerapkan model pembelajaran PBL. Tempat penelitian di SMPN 1 Tempeh. Sampel penelitian yaitu kelas VII-E. Penelitian menggunakan metode action research. Tes merupakan teknik pengumpulan data yang digunakan dalam penelitian. Instrumen yang digunakan dalam penelitian meliputi soal ulangan harian. Validasi data menggunakan excel. Bentuk tes essay (uraian obyektif). Berdasarkan hasil perhitungan bahwa rerata nilai sebesar 81.05 pada ulangan harian siklus pertama dan rerata nilai sebesar 94.74 pada ulangan harian siklus kedua, menunjukkan hasil ulangan harian siklus kedua lebih tinggi dari siklus pertama, kenaikan nilai ulangan harian sebesar $14.45 \%$. Kesimpulannya, model pembelajaraan PBL yang berpusat pada siswa, siswa menemukan masalah dan memecahkan jawaban masalah merupakan hasil karya siswa yang mampu meningkatkan hasil belajar IPA materi energi.
\end{abstract}

Kata Kunci : Pembelajaran berbasis masalah, Hasil Belajar Siswa.

\begin{abstract}
The research aims to improve student learning outcomes in science subjects by applying the PBL learning model. Place of research at SMPN 1 Tempeh. The research sample is class VII-E. Research using action research method. The test is a data collection technique used in research. The instruments used in the study included daily test questions. Data validation using excel. Essay test form (objective description). Based on the results of calculations that the average value is 81.05 in the first cycle of daily repetition and the average value is 94.74 in the second cycle of daily repetition, indicating that the results of the second cycle of daily repetition were higher than the first cycle, an increase in the daily repetition value of $14.45 \%$. In conclusion, the student-centered PBL learning model, where students find problems and solve problems, is the work of students who are able to improve science learning outcomes in energy materials.
\end{abstract}

Keywords: Problem-based learning, Student Learning Outcomes.

This is an open access article under the Creative Commons Attribution 4.0 International License 


\section{PENDAHULUAN}

Perubahan tingkah laku yang terjadi setelah mengikuti pembelajaran dalam aspek pengetahuan, sikap dan gerak merupakan hasil dari belajar (Purwanto, 2011;Aqib, 2010). Proses belajar sebagai transfer informasi dari guru pada peserta didik (Mulyana, 2020). Berdasarkan pendapat pakar tentang hasil belajar di atas, dapat disimpulkan bahwa hasil belajar adalah perubahan tingkah laku peserta didik yang terjadi setelah mengikuti pembelajaran. Angka atau nilai sebagai hasil dari perubahan tersebut meliputi aspek pengetahuan, sikap dan gerak.

Hasil belajar siswa kelas VII E dalam mata pelajaran IPA masih belum memuaskan. Rendahnya hasil belajar siswa ini diduga disebabkan berbagai faktor. Faktor yang berasal dari siswa itu sendiri dan guru yang mengajar. Metode ceramah, tanya jawab, praktikum dan diskusi merupakan metode yang sering digunakan dalam pembelajaran. Problem Based Learning (PBL) merupakan model pembelajaran yang direncanakan agar siswa mendapat pengalaman, yang membuat peserta didik belajar memecahkan masalah, dan memiliki pola pikir sendiri. Proses pembelajarannya menggunakan pendekatan yang melibatkan peserta didik untuk memecahkan masalah atau menghadapi tantangan yang diperlukan dalam kehidupan sehari-hari dalam dunia nyata. (Sahaja, 2016)

Menurut Saputra, model pembelajaran PBL diawali dengan adanya pertanyaan atau masalah, memusatkan pada pemecahan masalah berdasarkan ilmu yang dimiliki oleh peserta didik, penyelidikan nyata, kerja sama dan menghasilkan karya serta peragaan. PBL dirancang untuk membantu peserta didik mendapatkan informasi sebanyak-banyaknya. Pembelajaran yang menggunakan masalah nyata (autentik) yang tidak terstruktur dan bersifat terbuka sebagai konteks bagi peserta didik untuk mengembangkan keterampilan menyelesaikan masalah dan berfikir sendiri serta sekaligus membangun pengetahuan baru merupakan ciri dari PBL. (Saputra, 2020) Kesimpulan dari pembahasan model pembelajaran PBL yaitu pembelajaran PBL merupakan inovasi dalam pembelajaran, berpusat pada siswa, siswa menemukan masalah dan siswa (kelompok) juga yang memecahkam masalah.

Kondisi saat ini menunjukkan adanya wabah Covid-19 yang penyebarannya dapat terjadi sangat cepat. Sehingga, perlu adanya langkah yang tepat dalam menghambat penyebarannya. Untuk menghambat penyebaran Covid-19, manusia dilarang berkumpul, sekolah melarang siswa masuk kelas, pembelajaran dilakukan secara daring, pembelajaran jarak jauh, siswa menggunakan handphone dan laptop. Guru diharapkan menciptakan susasana yang kondusif bagi para siswanya dalam mengikuti proses pembelajaran jarak jauh. Masalah yang muncul, yaitu : Bagaimana meningkatkan hasil belajar siswa pada pembelajaran daring?

Berdasarkan identifikasi masalah maka masalahnya dirumuskan sebagai berikut: Bagaimana meningkatkan nilai ulangan harian IPA dengan cara PBL pada siswa SMPN1 Tempeh?

Berdasarkan rumusan masalah tersebut, maka tujuan yang ingin dicapai melalui penelitian ini yaitu: Meningkatkan hasil belajar siswa pada mata pelajaran IPA dengan menerapkan model pembelajaran PBL di SMPN 1 Tempeh. 
Action research merupakan metode yang digunakan di penelitian ini. Tes merupakan teknik pengumpulan data yang digunakan dalam penelitian. Bentuk tes essay (uraian obyektif), jumlah butir soal sebanyak sepuluh, digunakan untukinstrumen.

\section{METODE PENELITIAN}

Penelitian menggunakan "action research dilakukan untuk memperbaiki atau menyempurnakan pembelajaran terhadap masalah yang dihadapi di kelasnya sendiri (Cresswell,2008., Gall dkk, 2003; Sukmadinata, 2010). Langkah - langkah penelitian berupa identifikasi masalah, rencana tindakan, tindakan dan refleksi/evaluasi seperti pada Gambar 1. Data berupa hasil tes penguasaan konsep yang dilakukan melaui soal tes yang sudah divalidasi.

Siklus 1:
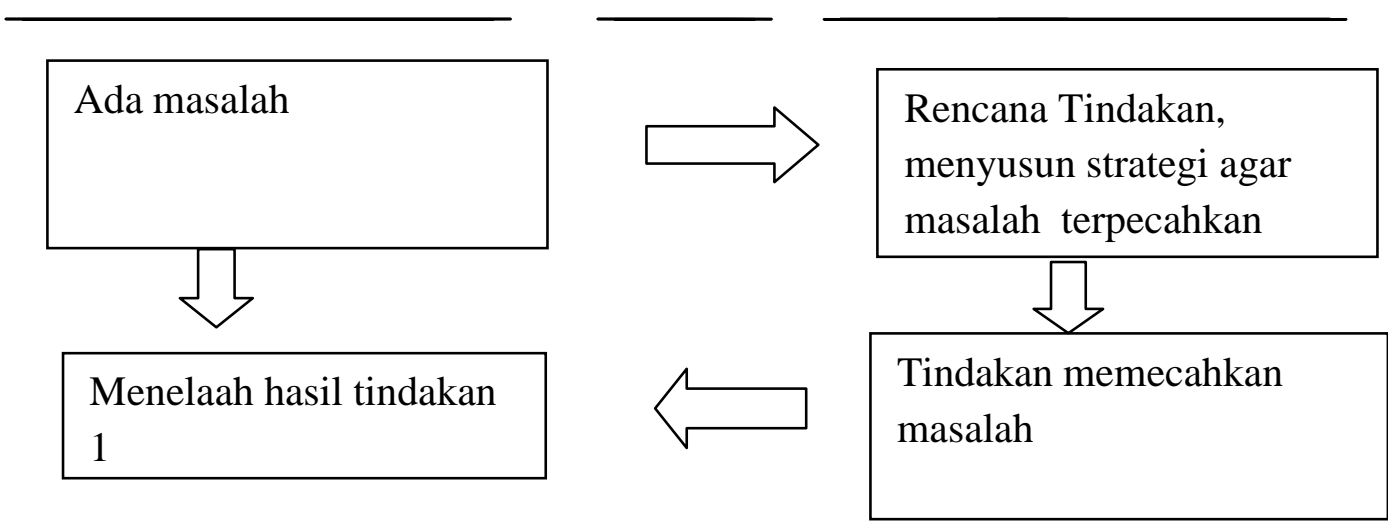

\section{Siklus 2 :}

Melanjutkan memecahkan
masalah yang belum
selesai

Menelaah hasil tes 2

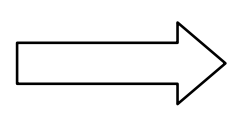

Rencana Tindakan, menyusun strategi agar masalah terpecahkan

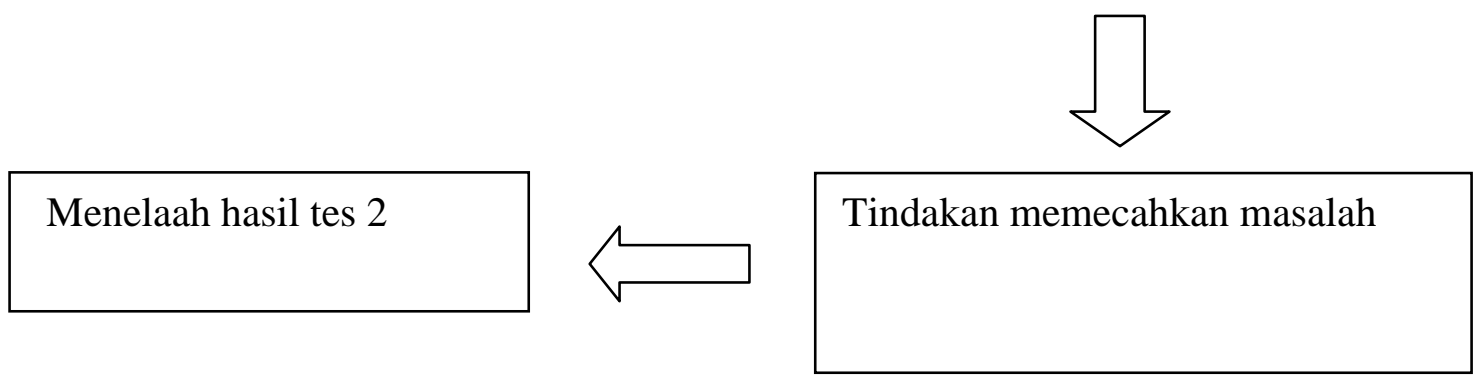

Gambar 1: Langkah-langkah Penelitian Tindakan

Peserta didik kelas VIIE SMPN 1 Tempeh sebagai sampel dalam penelitian. Pada pembelajaran jarak jauh menggunakan handphone, tidak semua siswa punya pulsa yang cukup, dari kelas VIIE tersebut yang aktif mengikuti PJJ ada 19 siswa. Data diperoleh dari hasil belajar yang diukur dengan tes tulis berbentuk soal uraian, validasi data menggunakan software, yakni excel. 
Teknik analisis data hasil ulangan harian berupa rerata serta persentase ketuntasan belajar untuk mendeskripsikan hasil ulangan siswa dalam pembelajaran.Untuk menghitung nilai ulangan harian siswa pada siklus pertama dan siklus kedua menggunakan excel.

\section{HASIL DAN PEMBAHASAN}

Hasil pengamatan pada siklus pertama setelah pembelajaran silkus pertama selesai, siswa diberikan ulangan harian. Rerata, nilai terendah tertinggi hasil ulangan harian pertama dapat dilihat pada Tabel 1 berikut ini:

Tabel 1. Rerata, Nilai Terendah Tertinggi Ulangan Harian Pertama

\begin{tabular}{clc}
\hline No & \multicolumn{1}{c}{ Ulangan Harian Pertama } & Nilai \\
\hline $\mathbf{1}$ & Nilai Rerata & 81.05 \\
\hline $\mathbf{2}$ & Nilai Terendah & 60 \\
\hline $\mathbf{3}$ & Nilai Tertinggi & 90 \\
\hline
\end{tabular}

Dari Tabel 1, diketahui nilai terendah 60 , nilai tertinggi 90, rerata nilai 81,05 . Jika dibuat distribusi frekuensi nilai siswa kelas VII-E ulangan pertama, hasilnya seperti tercantum pada tabel 2 .

Tabel 2. Distribusi Frekuensi Nilai Siswa Kelas VII-E Ulangan Harian Pertama

\begin{tabular}{ccccc}
\hline No & Nilai & Frekuensi & Prosentase $(\%)$ & Kategori \\
\hline 1 & $90-100$ & 6 & 31.5 & Sangat Baik \\
\hline 2 & $75-89$ & 10 & 52.6 & Baik \\
\hline 3 & $65-74$ & 2 & 10.5 & Cukup \\
\hline 4 & $0-64$ & 1 & 5.2 & Kurang \\
\hline
\end{tabular}

Dari tabel 2, diketahui pada siklus I, siswa yang mendapat nilai 0 - 64 sebanyak1 siswa (5.2\%) dengan kategori kurang, nilai 65 - 74 sebanyak 2 siswa $(10.5 \%)$ dengan kategori cukup, nilai 75 - 80 sebanyak 10 siswa (52.6\%) dengan kategori baik, ada 6siswa (31.5\%) yang mendapat nilai 90 - 100 dengan kategori sangat baik.

KKM yang digunakan pada mata pelajaran IPA adalah 75, sehingga perolehan nilai dibawah KKM dinyatakan belum tuntas. Ketuntasan belajar ulangan harian pertama tercantum pada Tabel 3.

Tabel 3. Ketuntasan Hasil Ulangan Harian Pertama

\begin{tabular}{ccccl}
\hline Nomor & Nilai & Frekuensi & Prosentase $(\%)$ & Kategori \\
\hline $\mathbf{1}$ & $75-100$ & 16 & 84.2 & Tuntas \\
\hline $\mathbf{2}$ & $0-74$ & 3 & 15.7 & Belum Tuntas \\
\hline
\end{tabular}

Dari Tabel 3, diketahui pada siklus I, siswa yang mendapat nilai 0 - 74 sebanyak3 siswa (15.7\%) dengan kategori belum tuntas, sedangkan siswa yang mendapat nilai $75-100$ sebanyak 16 siswa (84.2\%) dengan kategori tuntas. 
Pada siklus I, dari Tabel 1, diketahui dan nilai terendah 60, nilai tertinggi 90, rerata nilai 81,05 , KKM sebesar 75. Dari tabel 2, diketahui pada siklus I, siswa yang mendapat nilai 0 - 64 sebanyak 1 siswa (5.2\%) dengan kategori kurang, nilai 65 - 74 sebanyak 2 siswa (10.5\%) dengan kategori cukup, nilai 75 - 80 sebanyak 10 siswa (52.6\%) dengan kategori baik, ada 6 siswa (31.5\%) yang mendapat nilai 90 - 100 dengan kategori sangat baik. Ada satu siswa yang dapat nilai kategori kurang dan dua siswa dapat nilai kategori cukup, menunjukkan hasil belajar belum maksimal. Dari Tabel 3, diketahui pada siklus pertama, siswa yang mendapat nilai 0 - 74 sebanyak 3 siswa $(15.7 \%)$ dengan kategori belum tuntas, sedangkan siswa yang mendapat nilai 75 - 100 sebanyak 16 siswa $(84.2 \%)$ dengan kategori tuntas. Ada tiga siswa di siklus I yang dapat nilai di bawah KKM dengan kategori belum tuntas, menunjukkan hasil ulangan belum maksimal. Hasil ulangan siklus pertama dengan pembelajaran konvensional belum maksimal karena berpusat pada guru, kurang melibatkan siswa untuk aktif berpikir kritis dan kreatif, diperlukan model pembelajaran yang dapat memaksimalkan hasil belajar. Model pembelajaran berbasis masalah, PBL yang berpusat pada siswa diharapkan mengaktifkan berpikir kritis dan kreatif siswa dan dapat meningkatkan hasil ulangan yang maksimal. PBL dilaksanakan pada siklus kedua.

Hasil pengamatan pada siklus kedua, setelah pembelajaran silkus kedu selesai, pertemuan berikutnya melaksanakan ulangan harian, rerata, nilai terendah tertinggi hasil ulangan harian kedua tertulis pada Tabel 4.

Tabel 4. Rerata, Nilai Terendah Tertinggi Ulangan Harian Kedua

\begin{tabular}{clc}
\hline Nomor & \multicolumn{1}{c}{ Ulangan Harian Kedua } & Nilai \\
\hline $\mathbf{1}$ & Nilai Rerata & 94.74 \\
\hline $\mathbf{2}$ & Nilai Terendah & 90 \\
\hline $\mathbf{3}$ & Nilai Tertinggi & 100 \\
\hline
\end{tabular}

Dari Tabel 4, diketahui hasil ulangan harian kedua, nilai terendah 90, nilaitertinggi 100, Nilai Rerata 94,74.

Ketuntasan belajar, dengan KKM 75, yang dapat nilai di bawah KKM berarti belum tuntas, yang dapat nilai sama dengan KKM dan diatas KKM berarti tuntas. Ketuntasan belajar ulangan harian kedua tercantum pada Tabel 5 .

Tabel 5. Ketuntasan Hasil Ulangan Harian Kedua

\begin{tabular}{cllll}
\hline Nomor & Nilai & Frekuensi & Prosentase (\%) & Kategori \\
\hline $\mathbf{1}$ & $75-100$ & 19 & 100 & Tuntas \\
\hline $\mathbf{2}$ & $0-74$ & 0 & 0 & Belum Tuntas \\
\hline
\end{tabular}

Dari Tabel 5, diketahui pada siklus II, siswa yang mendapat nilai $0-74$ sebanyak 0 siswa $(0 \%)$ dengan kategori belum tuntas, sedangkan siswa yang mendapatnilai 75 - 100 sebanyak 19 siswa (100\%) dengan kategori tuntas.

Perbedaan rerata nilai hasil ulangan harian pertama dibandingkan dengan reratanilai hasil ulangan harian kedua, maka hasilnya terdapat di Tabel 6. 
Tabel 6. Perbedaan Rerata Hasil Ulangan Harian Pertama dan Kedua

\begin{tabular}{lll}
\hline & Hasil Ulangan Pertama & Hasil Ulangan Kedua \\
\hline Rerata & 81.05 & 94.74 \\
\hline
\end{tabular}

Dari Tabel 6. Rerata nilai ulangan harian siklus pertama sebesar 81.05 dan reratanilai ulangan harian siklus kedua sebesar 94.74 menunjukkan hasil ulangan siklus kedua lebih tinggi dari siklus pertama, kenaikan hasil ulangan sebesar $=(94.74-81.05) / 94.74 \times 100 \%=$ $14.45 \%$. Prosentase kenaikan hasil ulangan sebesar $14.45 \%$, kesimpulannya model pembelajaraan PBL dapat meningkatkan hasil ulangan sebesar $14.45 \%$. Jika perbedaan rerata hasil ulangan pertama dan kedua dibuat grafik, makahasilnya terdapat pada Grafik 1.

Grafik 1. Perbedaan Rerata Hasil Ulangan Pertama dan Kedua

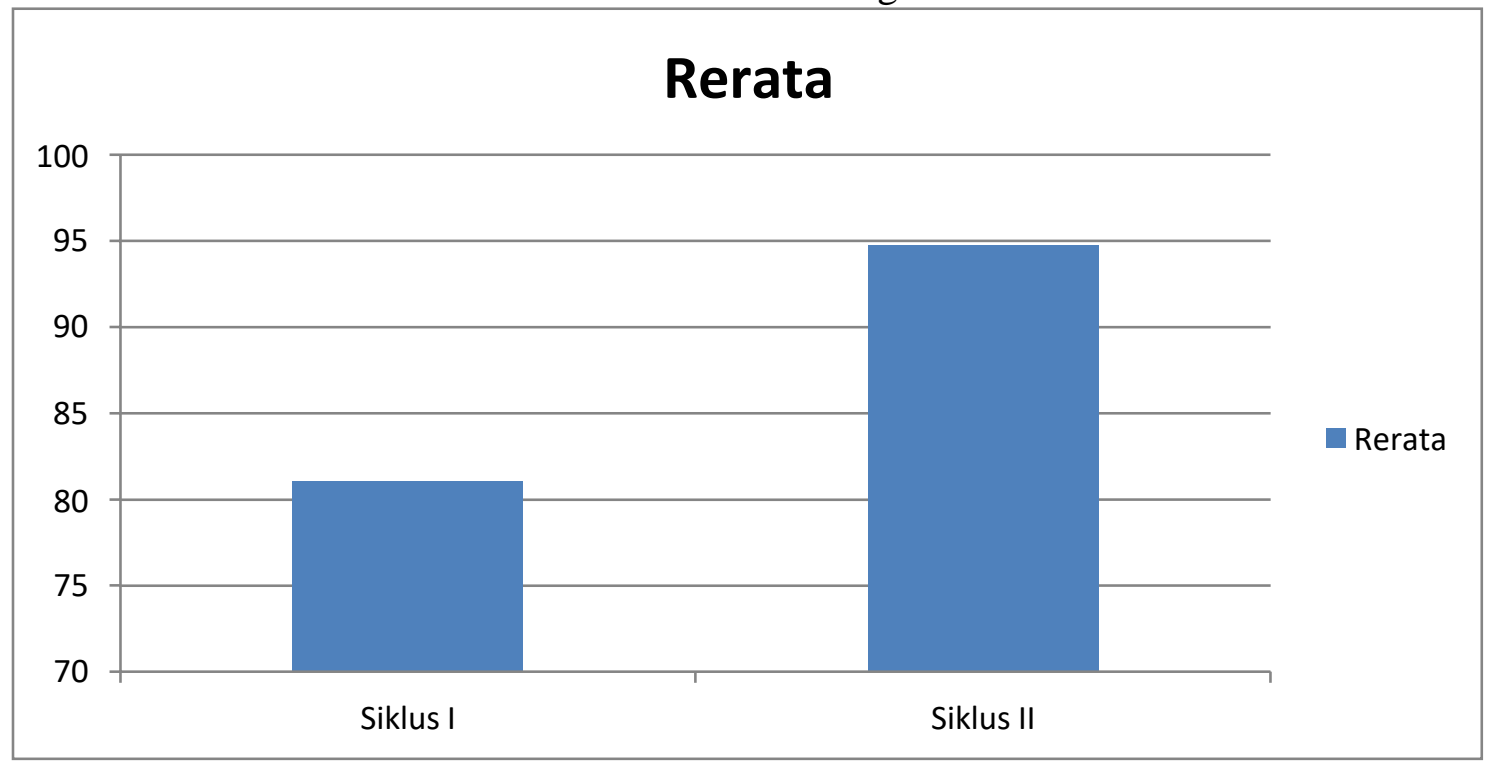

Rerata nilai ulangan harian siklus pertama sebesar 81.05 dan rerata nilai ulangan harian siklus kedua sebesar 94.74 menunjukkan hasil ulangan siklus kedua lebih tinggi dari siklus pertama, kenaikan hasil ulangan sebesar $=(94.74-81.05) / 94.74 \times 100 \%=14.45 \%$. Prosentase kenaikan hasil ulangan sebesar $14.45 \%$ kesimpulannya model pembelajaraan PBL dapat meningkatkan hasil ulangan sebesar $14.45 \%$. PBL yang berpusat pada siswa, siswa menemukan masalah dan memecahkan jawaban masalah merupakan hasil karya siswa yang mampu meningkatkan hasil ulangan.

Perbedaan nilai terendah dan tertinggi pada ulangan harian siklus pertama dan siklus kedua, hasilnya terdapat pada Tabel 7.

Tabel 7. Perbedaan Nilai Terendah dan Tertinggi Ulangan Harian Siklus pertama dan Siklus kedua

\begin{tabular}{ccc}
\hline & Nilai Terendah & Nilai Tertinggi \\
\hline Siklus I & 60 & 90 \\
\hline Siklus II & 90 & 100 \\
\hline
\end{tabular}


Perbedaan nilai terendah dan tertinggi pada ulangan harian siklus pertama dan Siklus kedua dibuat grafik, maka hasilnya terdapat pada Grafik 2.

Grafik 2. Perbedaan Nilai Terendah dan Tertinggi Ulangan Harian Siklus pertama dan Siklus kedua

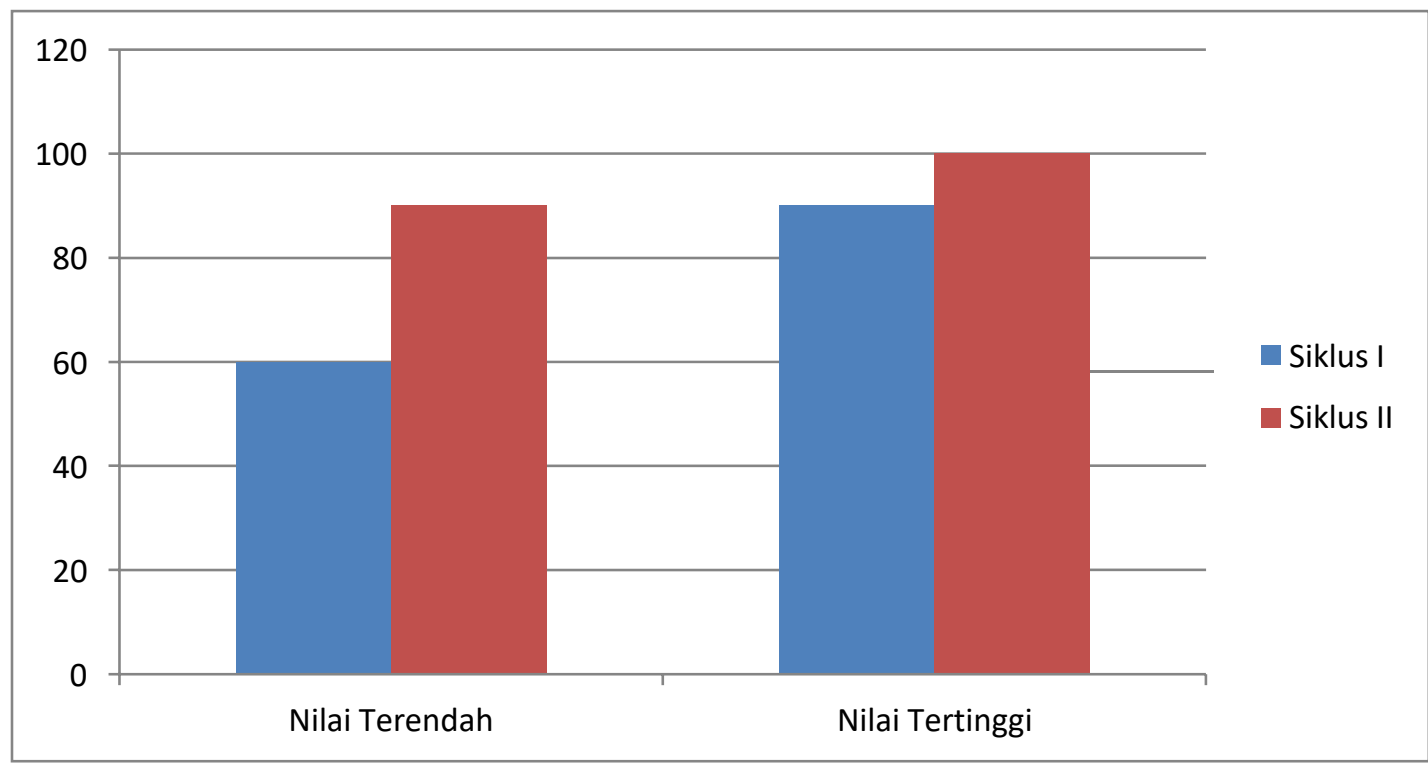

Ketuntasan hasil ulangan pada siklus pertama dan Siklus kedua dibandingkan, maka hasilnya terdapat pada Tabel 8 .

Tabel 8. Perbedaan Ketuntasan Hasil Ulangan Pertama dan Kedua

\begin{tabular}{lll}
\hline & Ulangan Pertama & Ulangan Kedua \\
\hline Belum Tuntas & $15.7 \%$ & $0 \%$ \\
Tuntas & $84.2 \%$ & $100 \%$ \\
\hline
\end{tabular}

Perbedaan ketuntasan hasil ulangan pertama dan kedua dibuat grafik, maka hasilnya terdapat pada Grafik 3.

Grafik 3. Perbedaan Ketuntasan Hasil Ulangan Siklus I dan Siklus II

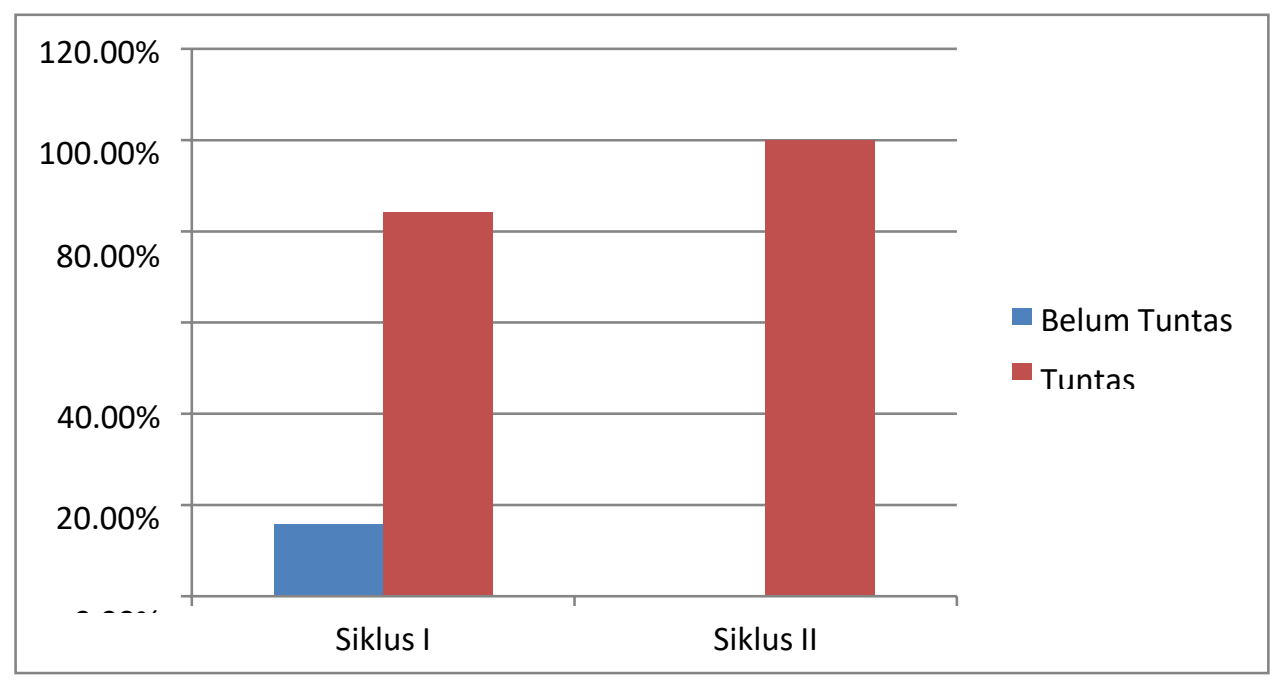


Dari Tabel 8, diketahui peserta didik yang mendapat nilai ulangan harian belumtuntas di siklus pertama sebesar $15.7 \%$ dan pada siklus kedua sebesar $0 \%$ (nihil), sedangkan yang tuntas di siklus pertama sebesar $84.2 \%$ dan pada siklus kedua sebesar $100 \%$. Ketuntasan pada siklus kedua lebih besar dari siklus pertama, maka dapat disimpulkan, model pembelajaraan berbasis masalah pada siklus kedua dapat meningkatkan ketuntasan hasil ulangan. PBL menggali berfikir dari pengetahuan yang didapat dalam memori otak siswa untuk memecahkan masalah yang dihadapinya, berdampak positif dalam meningkatkan ketuntasan hasil ulangan harian.

Perbedaan distribusi frekuensi nilai hasil ulangan siklus pertama dansiklus kedua dibuat tabel, maka hasilnya terdapat pada Tabel 9.

Tabel 9. Perbedaan Distribusi Frekuensi Nilai

\begin{tabular}{|c|c|c|c|c|c|}
\hline \multirow[t]{2}{*}{ Nilai } & \multicolumn{2}{|c|}{ Frekuensi } & \multicolumn{2}{|c|}{ Prosentase (\%) } & \multirow[t]{2}{*}{ Kategori } \\
\hline & Siklus 1 & Siklus 2 & Siklus 1 & Siklus 2 & \\
\hline $90-100$ & 6 & 19 & 31.5 & 100 & Sangat Baik \\
\hline 75 - 89 & 10 & 0 & 52.6 & 0 & Baik \\
\hline $65-74$ & 2 & 0 & 10.5 & 0 & Cukup \\
\hline $0-64$ & 1 & 0 & 5.2 & 0 & Kurang \\
\hline
\end{tabular}

Dari Tabel 9, diketahui perbedaan distribusi frekuensi nilai siklus pertama dan siklus kedua, ada 6 siswa (31.5\%) mendapat nilai ulangan harian dengan kategori sangatbaik di siklus pertama, sedangkan di siklus kedua, ada 19 siswa (100\%). Pada siklus pertama, ada 10 siswa (52.6\%) mendapat nilai ulangan harian dengan kategori baik, sedangkan di siklus kedua tidak ada siswa (0\%). Pada siklus pertama, ada 2 siswa (10.5\%) mendapat nilai ulangan harian dengan kategori cukup dan 1 siswa (5.2\%) kategori kurang, sedangkan di siklus kedua, tidak ada siswa $(0 \%)$. Adanya nilai siswa mendapat nilai ulangan harian dengan dengan kategori cukup dan kurang pada siklus pertama, sedangkan di siklus kedua tidak ada, menunjukkan belum maksimalnya hasil ulangan siklus pertama dengan model pembelajaran konvensional. Kesimpulannya model pembelajaran PBL pada siklus kedua dapat meningkatkan hasil ulangan harian dengan kategori sangat baik.

\section{KESIMPULAN}

Berdasarkan hasil perhitungan bahwa rerata nilai ulangan harian sebesar 81.05 pada siklus pertama dan rerata nilai ulangan harian sebesar 94.74 pada siklus kedua, menunjukkan hasil ulangan harian kedua lebih tinggi dari ulangan harian pertama,kenaikan hasil ulangan sebesar $14.45 \%$. Kesimpulannya model pembelajaraan PBL yang berpusat pada siswa, siswa menemukan masalah dan menemukan jawaban masalah merupakan hasil karya siswa yang mampu meningkatkan hasil ulangan IPA materi energi.

Nilai ulangan harian yang belum tuntas sebesar $15.7 \%$ di siklus pertama dan $0 \%$ (nihil) di ulangan harian siklus kedua, sedangkan yang tuntas sebesar $84.2 \%$ di siklus pertama dan $100 \%$ di siklus kedua. Ketuntasan nilai ulangan harian pada siklus kedua lebih besar dari siklus pertama, maka dapat disimpulkan, model pembelajaraan PBL pada siklus kedua dapat meningkatkan ketuntasan hasil ulangan harian. PBL menggali berfikir sendiri dari pengetahuan yang didapat dalam memori otak siswa untuk memecahkan masalah yang dihadapinya, berdampak positif dalam meningkatkan ketuntasan hasil ulangan harian. 


\section{DAFTAR RUJUKAN}

Gall,M.D.,Gall, J.P \& Bor,W.R.,2003, Educational Research An Inntorduction, SeventhEdition, Pearson Education Inc. USA.

Creswell, J.W.,2008.,Educational Research, Planning, Conducting and EvaluatingQuatintitative an Qualitative Research, Third Edition, Pearson Internatiional Edition.

Kurniawan, D. A. (2017). Retrieved November 9, 2020, from file:///C:/Users/client/Downloads/PENERAPAN_MODEL_PEMBELAJARAN_B ERBASIS_MASALAH_UNTU.pdf

Mulyana, A. (2020, Maret 2). Retrieved November 11, 2020, from https://ainamulyana.blogspot.com/2012/01/pengertian-hasil-belajar-danfaktor.html

Mulyana, A. (2020, Maret Selasa). Retrieved November Selasa, 2020, fromhttps://ainamulyana.blogspot.com/2012/02/minat-belajar.html

Sahaja, I. (2016, April 23). Retrieved November 12, 2020, from https://irwansahaja.blogspot.com/2016/04/model-pembelajaranberbasis-masalah.html

Saputra, H. (2020, April). Retrieved November 12, 2020, from file://C:/Users/client/Downloads/ModelPembelajaranBerbasisMasalahProblemBas edLearning.pdf

Sukmadinata,N.S., 2010, Metode Penelitian Pendidikan, Cetakan keenam, Rosda Karya,Bandung.

Sunaryo, Y. (2014). Retrieved November 9, 2020, from https://d1wqtxts1xzle7.cloudfront.net/58362919/209679-modelpembelajaran-berbasis-masalah-untu.pdf

Wijaya, I. W. (2015). Retrieved November 9, 2020, from https://www.neliti.com/publications/124560/pengaruh-modelpembelajaran-berbasis-masalah-terhadap-hasil-belajar-ipa-ditinjau 